\title{
Cross border mobility: what do we need in practice?
}

\author{
Vanessa Knapp ${ }^{1}$
}

Published online: 1 March 2018

(C) The Author(s) 2018. This article is published with open access at Springerlink.com

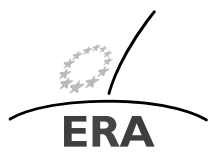

EUROPÄISCHE RECHTSAKADEMIE ACADEMY OF EUROPEAN LAW ACADEMIE DE DROIT EUROPEEN ACCADEMIA DI DIRITTO EUROPEO TRIER - TREVES - TREVIRI

\begin{abstract}
The European Commission is proposing to provide efficient rules for crossborder operations. This article suggests improvements to the cross-border merger provisions in the Consolidated Company Law Directive 2017/1132 to provide better creditor protection and minority shareholder protection, more use of the Business Registries Interconnection Service and a simpler process in simpler cases. It suggests provisions relevant for creditor protection in the case of cross-border divisions, the process to be followed for a cross-border division and a simpler process for simpler cases. It also suggests a process for cross-border conversions and provisions to protect creditors and minority shareholders.
\end{abstract}

Keywords Cross-border mobility · Cross-border merger · Cross-border division • Cross-border conversion · Business Registries Interconnection Service

\section{Introduction}

The Treaty on the Functioning of the European Union (TFEU) provides freedom of establishment for companies in the European Union (EU). ${ }^{1}$ Since 2005, the EU has had a Directive dealing with cross-border mergers of limited liability companies. ${ }^{2}$

\footnotetext{
${ }^{1}$ Arts. 49 and 54 TFEU.

${ }^{2}$ Directive 2005/56/EC of the European Parliament and of the Council of 26 October 2005 on cross-border mergers of limited liability companies [2005] OJ L 310/1.
}

\footnotetext{
Professor V.J. Knapp, OBE

vanessa.j.knapp@gmail.com

1 London, UK
} 
This Directive is now consolidated in Chap. 2 of the Consolidated Directive relating to company law (the Consolidated Directive). ${ }^{3}$ There is no equivalent EU legislation dealing with cross-border divisions or cross-border conversions of companies. There have been various cases, including Sevic, ${ }^{4}$ VALE $^{5}$ and Polbud, ${ }^{6}$ where the Court of Justice of the European Union (CJEU) has made it clear that the freedom of establishment extends to cross-border operations other than cross-border mergers. However, as cases deal with particular fact patterns, there is disagreement about the extent of this freedom and the process needed to exercise the freedom.

A study on the Cross-Border Mergers Directive in September $2013^{7}$ provided evidence that the Directive had brought about a new age of cross-border mergers activity. However, it also identified areas for potential improvement.

The European Commission (Commission) has been considering an initiative on cross-border divisions and a reform of the cross-border mergers provisions since 2012. ${ }^{8}$ The Commission conducted a consultation in 2014 and published a feedback statement in 2015. ${ }^{9}$ It also consulted on the cross-border transfer of registered offices in $2013 .^{10}$

The President of the Commission, Mr Jean Claude Juncker, announced in September 2017 in the State of the Union Address $2017^{11}$ that the Commission proposes to bring forward an EU company law package making the best of digital solutions and providing efficient rules for cross-border operations whilst respecting national social and labour law prerogatives. At the time of writing this article, this package has not yet been published but is expected shortly.

This article looks at various actions the Commission could take to improve the provisions relating to cross-border mergers, particular aspects to consider in introducing provisions to facilitate cross-border divisions of companies and some suggestions for particular provisions to facilitate cross-border conversions of companies from one Member State to another. The provisions suggested are intended to provide a process that will work well in practice both for the companies involved and for those affected by their proposals. It does not address the position of the protection of employees, a subject which is complex and worthy of a separate article.

\footnotetext{
${ }^{3}$ Directive 2017/1132 of the European Parliament and of the Council of 14 June 2017 relating to certain aspects of company law (codification) [2017] OJ L 169/46.

${ }^{4}$ Case C-411/03 Sevic, EU:C:2005:762.

${ }^{5}$ Case C-378/10 VALE, EU:C:2012:440.

${ }^{6}$ Case C-106/16 Polbud, EU:C:2017:804.

${ }^{7}$ Study on the application of the Cross-Border Mergers Directive by Bech-Bruun and Lexidale for the Directorate General for the Internal Market and Services, the European Union.

${ }^{8}$ Action Plan: European company law and corporate governance-a modern legal framework for more engaged shareholders and sustainable companies, COM (2012) 740 final.

${ }^{9}$ http://ec.europa.eu/internal_market/consultations/2014/cross-border-mergers-divisions/index_en.htm.

${ }^{10}$ http://ec.europa.eu/internal_market/consultations/2013/seat-transfer/index_en.htm.

${ }^{11} \mathrm{https} / / / \mathrm{ec}$. europa.eu/commission/sites/beta-political/files/state-union-2017-brochure_en.pdf.
} 


\section{Improvements to the cross-border mergers provisions in the Consolidated Directive}

The 2013 study on the Cross-Border Mergers Directive provided evidence that the number of cross-border mergers had increased 173\% between 2008 and 2012. This increase in activity was particularly impressive, as it happened against the background of a downturn in growth as a result of the global economic crisis, which led to a general reduction in merger activity. Member States were also quite slow in transposing the Directive, which may also have affected the impact. The study also found that the Directive had reduced the cost of group reorganisations, reduced regulatory costs and simplified the procedures that companies had to follow to achieve a crossborder merger of companies. However, the study also found that there were still some obstacles to cross-border mergers which could be removed. In particular, differences in the ways in which Member States provided protections for minority shareholders and for the creditors of merging companies posed practical problems for merging companies. The study also identified the absence of clear standards for communications between registries as an impediment and noted that it would be helpful for a simplified procedure to be available in more cases.

\subsection{Creditor protection}

Article 121(2) of the Consolidated Directive (previously Article 4(2) of the CrossBorder Mergers Directive) allows a Member State to include provisions and formalities, as part of its national law, to protect creditors. The concern for a creditor of a merging company is that the credit risk of the merged company may be different from that of the merging company and the law governing the merged company may differ in the way it deals with creditors from the law governing the merging company. There may also be some uncertainty as to who will be treated as a creditor of a merging company. The study demonstrated that different Member States take very different approaches to creditor protection. Some Member States set the creditor protection date before the shareholder meeting takes place, normally at the date of publication of the draft merger terms. Other Member States set the date after the shareholders meeting. The duration of the creditor protection period and the procedure to be followed can also vary widely. The variations are therefore both procedural and substantive and can cause problems for the merging companies, particularly in cases where the period for dealing with creditor protection differs.

It would therefore be very helpful if the Consolidated Directive were amended to provide a common approach to dealing with creditor protection. This could align who is treated as a creditor of the merging companies, the procedure a creditor should follow if it believes it should be protected from the merger, the time at which the steps would have to be taken, the remedies available to creditors and the circumstances in which these would be available. From the perspective of the merging companies, this would provide more certainty to the companies both as to whether they are likely to be required to provide any protection to their creditors, and that the process of providing creditor protection will not impede the merger due to differences in the timing of dealing with this aspect. 
The first question to answer is who should be treated as a creditor and should therefore be entitled to the benefit of any protection offered. The merging companies' common draft merger terms must state the date of the accounts of the merging companies used to establish the conditions of the cross-border merger. These accounts will show the merging companies' creditors at the date of those accounts. However, those accounts may be quite out of date and the companies will have continued to incur obligations, so the date for establishing a company's creditors should be set no earlier than the date for invoking the protection mechanism. The company may also have future and contingent creditors, for example where payment of the debt will become due at a date after the creditor protection procedure or where it is not yet clear whether the company will owe money to a third party. Common examples of contingent creditors include where proceedings have been brought against a company but the case has not yet been heard or where a company has potential obligations under an indemnity or a pension fund, but it is not yet clear if any condition to the obligation arising will be satisfied or what the amount owed will be. Such potential creditors should be able to benefit from any creditor protection system.

There should be a defined period in which creditors can invoke the creditor protection mechanism. It would be helpful for the merging companies and for their shareholders deciding whether to approve the merger or not if this period were to end before the shareholder meeting. In order to protect creditors and allow them access to information about the proposed merger the period should not start before publication of the draft merger terms. The study identified an ex-ante approach of this sort as providing certainty on the creditors' position when the merger takes effect but thought that it might lead to a delay in the merger. This will obviously depend on the national law process that applies to any application for protection and how quickly that can be dealt with in practice. However, further provisions on creditor protection could reduce this risk, by setting out situations in which a creditor would be deemed not to be prejudiced by a proposed merger. This would also provide more certainty for the merging companies, who would know that if they meet these criteria, creditors will not be eligible for any further protection.

The criteria should be based on whether the creditor is reasonably likely to be prejudiced by the proposed merger. A possible approach would be for an independent expert to determine whether there is a reasonable likelihood of the creditor being prejudiced by the merger. If not, then the creditor would not be entitled to protection. An alternative approach would be if the creditor's claim after the merger would be of an equivalent value to their original claim. Creditors may also feel that the place where they can bring their claim is important so, for example, a small creditor is not required to litigate in another jurisdiction following a merger. There could therefore also be a requirement that creditors must be entitled to bring their claim in the same jurisdiction as before the merger. The credit quality of the claim after the merger should be at least as good as before the merger. The merging companies should be free to choose either of these approaches or a combination of both of them.

\subsection{Minority shareholder protection}

The Consolidated Directive specifically allows Member States to provide protections for minority shareholders who have opposed a cross border merger. Minority share- 
holders who do not vote in favour of a merger may have concerns about being a minority shareholder in the merged company. These concerns may be that the company law of the merged company or the articles of association of the merged company will not give them the same protections as they have before the merger or that the exchange ratio being offered for their shares or other securities is inadequate. They may therefore want to sell their shares in the merging company for cash or to be able to challenge the exchange ratio offered. From the merging companies' perspective, there is a concern that the company may be required to buy out a large number of minority shareholders for cash (which can have a significant effect on the merged company) and that, if the exchange ratio is determined to have been set inadequately, this will undermine the basis for the merger. For these reasons, it would be helpful if the time period for minority shareholders to exercise any rights to protection were limited to a short period after the general meeting, so that the merging companies will know at an early stage what the position is likely to be.

The European Parliament Report on cross-border mergers and divisions, ${ }^{12}$ considered it important that future legislative proposals should include maximum harmonisation provisions and thought it important to make improvements to the rights of minority shareholders. To harmonise the approach adopted in the EU, a merging company could be required to pay adequate cash compensation to any shareholder who votes against the merger if they will become a shareholder in a merged company in a different jurisdiction. Payment of the cash compensation should be conditional upon the merger completing. A merging company may also have shareholders who hold non-voting shares. In this case, such non-voting shareholders should also be able to claim adequate cash compensation, conditional upon the merger completing, if they will become a shareholder of the merged company in a different jurisdiction. There should also be a right for the adequacy of the cash compensation to be reviewed by an independent expert. The merging companies may be concerned that they will be adversely affected if they are required to pay cash compensation to a large number of minority shareholders. However, they should be able to protect themselves against this by including a condition dealing with this in the draft merger terms.

For cases where the exchange ratio is thought to be inadequate, the merged company could be required to pay compensation to the relevant minority shareholders on the basis of an adequate ratio. This could be paid either in cash or by providing additional shares or securities of the merged company. This remedy should not be available to a minority shareholder who has elected to have their shares bought out for cash. Minority shareholders are likely to want to bring an action against the merging company in the jurisdiction where the merging company is located. It is likely to make any proceedings more manageable as far as the company is concerned if this is an exclusive jurisdiction. However, it may also be sensible for the law applicable to the merged company to be the law that governs any obligation to pay additional cash or to provide additional shares, as it is the merged company that will have to pay the cash or issue additional shares to minority shareholders of the merging company or companies.

${ }^{12} 9$ May 2017, 2016/2065(INI). 


\subsection{A better process}

Since the Cross-Border Mergers Directive was originally introduced, there have been many advances in the ways in which companies communicate information to their shareholders and the public and in the ways in which the competent authorities responsible for dealing with companies communicate with each other. The Business Registries Interconnection Service (BRIS) ${ }^{13}$ went live on 8 June 2017. BRIS connects the business registers of the Member States to a European central platform and allows a single point of access to information on companies and branches in the EU.

The Consolidated Directive could be amended to allow merging companies and the competent authorities responsible for dealing with cross-border mergers to make better use of digital technology. In particular, a merging company could be allowed to make its draft merger terms available free of charge on its website for a fixed period before the shareholders meeting, rather than having to publish them in another manner. Merging companies should be able to provide any information they are required to provide to the relevant competent authority in connection with the merger digitally and should not be required to appear physically in the relevant Member State. In addition, it would help to speed up the process if the relevant competent authorities were required to provide information (for example, relating to the issue of a pre-merger certificate and the issue of a certificate that the merger has completed) to each other in a standard format through BRIS.

Another improvement to the process would be for the Consolidated Directive to be amended to make it clear that the entry into effect of a merger cannot be challenged on the basis that cash compensation for minority shareholders is inadequate or that the share exchange ratio was inadequate. The only remedies for minority shareholders would be to seek the protections for minority shareholders set out in the amended Consolidated Directive (as suggested above), rather than challenging the merger entering into effect.

\subsection{A simpler process for simpler cases}

The Cross-Border Mergers Directive contained a provision for a simplified process where a cross-border merger by acquisition was carried out by a company which held all the shares and other securities conferring the right to vote in the company or companies being acquired. ${ }^{14}$ For example, there is no need for an independent expert report or for approval of the merger by a shareholder meeting of the company or companies being acquired. It also gave Member States the option to allow a simplified process where a cross-border merger by acquisition was carried out by a company which held $90 \%$ or more of such shares or other securities in the company or companies being acquired.

\footnotetext{
${ }^{13}$ Established on the basis of Directive 2012/17/EU of the European Parliament and of the Council of 13 June 2012 amending Council Directive 89/666/EEC and Directives 2005/56/EC and 2009/101/EC of the European Parliament and of the Council as regards the interconnection of central, commercial and companies registers [2012] OJ L 156/1.

${ }^{14}$ Now Art. 132(1) of the Consolidated Directive (originally Art. 15(1) of the Cross-Border Mergers Directive).
} 
The Consolidated Directive does not allow a simplified process to be followed where the same person (or that person and others acting on their behalf) holds all the shares and other securities conferring the right to vote in all the merging companies. There does not seem to be any reason why a simplified process should not be allowed in such a case and it would be helpful for the Consolidated Directive to be amended accordingly.

\section{Cross-border divisions}

In her study for the JURI Committee on cross-border mergers and divisions, transfers of seat, ${ }^{15}$ Dr. Jessica Schmidt recommended that the Cross-Border Mergers Directive should be extended into a Cross-Border Mobility Directive. She referred to the VALE case ${ }^{16}$ as establishing that cross-border conversions are protected by freedom of establishment but her report said that the freedom to divide was largely illusory because of the legal uncertainty and high risk of failure that deter companies from trying to divide cross-border. Given that divisions can be characterised as the 'mirror image' of mergers, she recommended that cross-border divisions should generally be governed by rules reflecting the rules for cross-border mergers.

Whilst it is sensible that the approach used for cross-border mergers should be used as the basis for rules on cross-border divisions, there are some differences between cross-border mergers and cross-border divisions, where further provisions will be needed if cross-border divisions are to balance the company's needs and those of its creditors. There are also some improvements to the process for cross-border divisions that could usefully be made.

\subsection{Creditor protection}

Where a company divides itself into one or more companies, at least one of which will be governed by the law of a different Member State, the creditors of the company will be concerned to know which company they will be a creditor of after the division. They will also be concerned to know whether that company will be equally able to pay the debt it owes when it becomes due and whether the creditor will have to bring proceedings in a different Member State against the company, compared to where it would have brought proceedings against the dividing company.

The protection of creditors of a public limited liability company that divides in a national division have already been considered at EU level in the Sixth Council Directive of 17 December 1982 (now Articles 135 to 160 of the Consolidated Directive). ${ }^{17}$ These provisions require Member States to provide an adequate system of protection for the interests of the creditors of the companies involved in a division whose claims antedate publication of the draft terms of division and have not yet fallen due at the

\footnotetext{
${ }^{15}$ Schmidt [2].

${ }^{16}$ Case C-378/10 VALE, EU:C:2012:440.

${ }^{17}$ Sixth Council Directive 82/891/EEC of 17 December 1982 based on Article 54 (3) (g) of the Treaty, concerning the division of public limited liability companies [1982] OJ L 378/47.
} 
time of such publication. The creditors must be entitled to obtain adequate safeguards where the financial situation of the company being divided, and that of the company to which the obligation is to be transferred in accordance with the draft terms of division, make such protection necessary, and where those creditors do not already have such safeguards. They must be able to apply for adequate safeguards provided that they can credibly demonstrate that, due to the division, the satisfaction of their claims is at stake and that no adequate safeguards have been obtained from the company.

If a creditor has not obtained satisfaction, the Consolidated Directive provides that the recipient companies must be jointly and severally liable for that obligation. Member States may limit that liability to the net assets allocated to each of those companies other than the one to which the obligation has been transferred. However, Member States need not apply this approach where two requirements are satisfied. The first is that the division operation is subject to the supervision of a judicial authority with the power to call a creditors' meeting and ensure that the creditors can obtain the draft terms of division before that meeting. The second is that a majority in number representing three-quarters in value of the creditors or any class of creditors of the company being divided have agreed to forego such joint and several liability at a meeting. There is also a Member State alternative option to provide that the recipient companies shall be jointly and severally liable for the obligations of the company being divided. If this alternative approach is adopted, they need not apply the previous requirements. They can limit this joint and several liability to the net assets allocated to each company if they combine this approach with the alternative approach.

If changes to the Consolidated Directive adopt a similar approach, this will provide considerable protection for creditors. An alternative or additional approach could be to require all the directors of the dividing company to make a declaration of solvency that they are unaware of any reason why the dividing company (if it will still exist after the division) and the recipient company or companies will be unable to meet their liabilities when they fall due. In order for directors to be willing to make such a declaration, it should be clear that the declaration would be based on the information available to them when the declaration is made. However, to give third parties reassurance that the directors have met their responsibilities as directors, it should also be clear that the directors should have made reasonable enquiries before making the declaration and that the declaration should be made no more than a stated time before the draft division terms are published (so that there is reassurance that the declaration of solvency is up-to-date).

One of the potential difficulties of a division is that the draft division terms may fail to allocate all the company's liabilities. It is therefore important that provisions are included to set out how such liabilities should be dealt with. One way to deal with this is to require the draft cross-border division terms to set out how any liabilities unknown at the date of the draft terms are to be allocated. Such liabilities might arise because a claim for compensation is made after the draft terms are published or because of events happening after that date but before the division takes effect. However, it would also be sensible for there to be a default rule to deal with any such unknown liabilities. The approach adopted by the Consolidated Directive of making the recipient companies jointly and severally liable for the unknown liability, with the obligation being limited to the net assets allocated to them, would offer sensible protection in such cases. 


\subsection{The process}

The process followed to approve and authorise a division will need to be slightly different from that for a cross-border merger. A company involved in a cross-border division (whether it is the company that will be divided or a company receiving assets and/or liabilities from the dividing company) should be required to submit the draft cross-border division terms to the relevant competent authority for scrutiny. Each competent authority should be required to scrutinise the part of the procedure relevant to the company being divided or involved in the division which is governed by its law. Companies involved in the process should be able to provide the relevant information to the competent authority digitally without having to be physically present in the relevant Member State. Each competent authority should be required to issue a certificate (assuming it is satisfied) that the pre-division acts have been properly completed and this should be made available digitally to the other competent authorities concerned. The competent authority of the company being divided should be the relevant authority to determine if and when the cross-border division should complete, which should only be possible once all the relevant competent authorities have confirmed that the pre-division acts have been properly completed. The competent authority should communicate this digitally through BRIS to the other competent authorities and also to the competent authorities in any Member State where the relevant companies have a branch.

\subsection{A simpler process for simpler cases}

The Consolidated Directive ${ }^{18}$ allows the public company being divided in a national division to dispense with a general meeting if the recipient companies together hold all the shares of the company being divided and all other securities conferring the right to vote at general meetings of the company being divided and certain other conditions are met. In the same way as for cross-border mergers, it would be sensible for a simplified process for cross-border divisions also to apply where one person (or that person and those holding on their behalf) hold all the shares and other voting securities in all the companies involved in the division. It would also be sensible for there to be a simplified process where the dividing company is transferring assets and liabilities to one or more recipient companies which are its wholly-owned subsidiaries.

\section{Cross-border conversions}

At the moment, EU law does not set out a specific process for limited liability companies to follow if they wish to exercise their freedom of establishment and become a company subject to the laws of a different Member State. There are provisions at EU level which allow a Societas Europaea to transfer its seat across borders ${ }^{19}$ and which

\footnotetext{
${ }^{18}$ Art. 154.

${ }^{19}$ Council Regulation (EC) No. 2157/2001 of 8 October 2001 on the Statute for a European company (SE) [2001] OJ L 294/1; Council Directive 2001/86/EC of 8 October 2001 supplementing the Statute for a European company with regard to the involvement of employees [2001] OJ L 294/22.
} 
allow a Societas Cooperativa Europaea (European Cooperative Society) ${ }^{20}$ to do the same.

The CJEU indicated obiter in the Cartesio case ${ }^{21}$ and then held explicitly in the VALE case that cross-border transfers of seat (cross-border conversions) are protected by the freedom of establishment pursuant to Articles 49 and 54 TFEU. In Polbud $^{22}$ the CJEU held that Articles 49 and 54 TFEU do not, in principle, preclude certain Member State measures intended to protect the interests of creditors, minority shareholders and employees of a company that has been incorporated under the law of that Member State which is to continue to carry on business in the national territory. The measures are those intended to ensure those interests are not improperly affected by the transfer of the company's registered office and its conversion into a company under the law of another Member State. However, any restriction must be appropriate to protect those interests and must not go beyond what is needed to achieve that objective. In the Polbud case, a requirement for a mandatory liquidation of the company that wanted to move its registered office from Poland to Luxembourg was held to go too far in protecting creditor interests. The Court also held that whilst it is open to the Member States to adopt any appropriate measure for preventing or penalising fraud, the fact that either the registered office or real head office of a company was established in accordance with the legislation of a Member State for the purpose of enjoying the benefit of more favourable legislation does not, in itself, constitute abuse. Moreover, the mere fact that a company transfers its registered office from one Member State to another cannot be the basis for a general presumption of fraud and cannot justify a measure that adversely affects the exercise of a fundamental freedom guaranteed by the Treaty.

Like the lack of a specific process for cross-border divisions, the lack of a specific process for limited liability companies to follow if they wish to convert from being a company in one Member State to being a company in a different Member State means that, in practice, the freedom of establishment is largely illusory. Most companies are unwilling to litigate to establish their right to move from one Member State to another because of the costs of doing so and the time this will take. Competent authorities in most Member States do not know what to tell a company that approaches them about the steps they should follow to exercise the right to convert. There is also uncertainty for the creditors, shareholders and other stakeholders of a company that wishes to convert.

The Commission has considered bringing forward a legislative proposal for a cross-border conversion since $1997 .{ }^{23}$ In Resolution 2011/2046(INL) on a 14th company law directive on the cross-border transfer of company seats adopted on 2 February 2012, the European Parliament called on the Commission to facilitate cross-

\footnotetext{
${ }^{20}$ Council Regulation (EC) No 1435/2003 of 22 July 2003 on the Statute for a European Cooperative Society (SCE) [2003] OJ L 207/1; Council Directive 2003/72/EC of 22 July 2003 supplementing the Statute for a European Cooperative Society with regard to the involvement of employees [2003] OJ L 207/25.

${ }^{21}$ Case C-210/06 Cartesio, EU:C:2008:723.

${ }^{22}$ Case C-106/16 Polbud, EU:C:2017:804.

${ }^{23}$ Proposal for a Fourteenth European Parliament and Council Directive on the transfer of the registered office of a company from one Member State to another with a change of applicable law, YV/D2/6002/97EN REV. 2.
} 
border mobility for companies. The idea of a legislative proposal was raised again in the 2012 Action Plan ${ }^{24}$ and the Commission consulted on the costs faced by companies transferring their registered offices abroad and on the range of benefits that could be brought by EU action on the cross-border transfer of registered offices in 2013. ${ }^{25}$ In 2014, the Commission commissioned a report on the conflict of law rules applicable to companies. The Final Report was published in April 2017. ${ }^{26}$ The main finding of the empirical survey undertaken was that there are significant practical obstacles to corporate mobility in Europe. The Report suggested that a directive of substantive company law should be adopted to provide for harmonised rules and procedures to allow a company created under the law of a Member State to convert into a company governed by the law of another Member State, without the company being wound up or the creation of a new legal person. It said that a Directive should harmonise procedures for implementing cross-border reincorporations and provide minimum harmonisation of the rules on creditor protection, with the aim of avoiding opportunistic reincorporations at the expense of creditors and other stakeholders.

There are obvious differences between the case of a company that moves from one Member State to another, compared to either a cross-border merger or a cross-border division. In a cross-border conversion, there is no change in the assets or liabilities of the company concerned, and so no effect on the creditworthiness of the company. Also, the shareholders of the company will remain shareholders in the company, with no change in the percentage of their holding in the company. However, this does not mean that there are no differences for creditors or shareholders. The law governing the company in its new Member State may treat creditors differently if the company becomes insolvent and may give priority to different creditors or give priority to a greater or smaller extent. The law of the new Member State may not recognise a particular form of security recognised in the original Member State. For shareholders, the law of the new Member State may not offer the same rights and protections for shareholders as the law of the original Member State, for example a right to require an investigation of the company or recognition of particular share rights.

\subsection{A clear process}

As the process for cross-border mergers has worked well in practice, it would seem sensible to use this as a basis for the process for a cross-border conversion (including any changes that are made to the cross-border mergers process, as suggested in 2 above). This would involve requiring the company that wishes to move to a new Member State to publish draft terms of conversion before holding a general meeting of shareholders who are to decide on the conversion. The draft terms of conversion would set out information about the proposed conversion and would be required to contain some minimum information. This should include the form the company will

\footnotetext{
${ }^{24}$ Action Plan: European company law and corporate governance—a modern legal framework for more engaged shareholders and sustainable companies, $\operatorname{COM}(2012) 740,4.1$.

${ }^{25}$ Consultation document, contributions and feedback statement available at http://ec.europa.eu/internal_ market/consultations/2013/seat-transfer/index_en.htm.

${ }^{26}$ Gerner-Beuerle/Mucciarelli/Schuster/Siems [1].
} 
take in the new Member State, its name and registered office, its proposed constitution, changes to the rights of shares and other securities as a result of the conversion, when it is proposed the conversion will take place and information on creditor and minority shareholder protection. The draft terms of conversion should be made publicly available for a minimum period before the general meeting. As in the case of a cross-border merger, there should be a report of the management or administrative organ of the company to the members, explaining the reasons for, and implications of, the proposal for the company and its members. A member or creditor of the company should be able to ask a competent authority to appoint an independent expert to prepare a written report within a stated period if there are concerns about the report provided by the company. The proposed conversion should be subject to approval at a general meeting of the company.

The company should be able to provide information about the proposed conversion to the competent authority in its original Member State and in the proposed new Member State in digital form without having to be physically present there. The competent authority of the original Member State should be responsible for determining if the required pre-conversion acts have been properly carried out or not. The competent authority of the proposed new Member State should be responsible for determining if the company will meet the relevant requirements for the company form chosen on conversion. The relevant competent authorities should provide information to each other digitally in a standard format through the BRIS system.

The competent authority of the proposed new Member State should be responsible for determining the date on which the conversion takes place. This date should fall after the original Member State has confirmed that the company has properly met the pre-conversion acts. The competent authority of the proposed new Member State should be required to notify the original Member State when the conversion takes effect and also to notify any other competent authorities affected, for example where the company has a branch.

The proposal should set out the consequences of the cross-border conversion, including that the company will continue to have all its assets and liabilities. It would be helpful to state specifically what the position will be if the company is not immediately removed from the register of companies in its original Member State. It would be sensible for third parties to be able to continue to rely on the registered office in the original Member State unless they knew about (or could not have been unaware of) the registered office in the Member State to which the company has moved.

\subsection{Protection of creditors}

Concerns have been expressed that a company wishing to convert to a different Member State may wish to do so to avoid its obligations to creditors. ${ }^{27}$ A concern that the company may wish to move in order to avoid its liabilities could be addressed in the same way as suggested in paragraph 3 above for cross-border divisions. All the directors of a company wishing to convert would be required to make a declaration, based on the information available to them at the date of the declaration, that they

${ }^{27}$ See, for example, Simon [3]. 
do not know of any reason why the company would be unable to meet its liabilities when they fall due after the conversion. As for a cross-border division, this declaration should be made having made reasonable enquiries and should be made at a date no more than a stated period before the draft cross-border conversion terms are published.

A creditor of a company that wishes to convert, which should include future and contingent creditors, should be able to seek protection from a court or other competent authority in the original Member State if they can show that they are reasonably likely to be prejudiced by the conversion. To provide certainty for both creditors and the company, there should be a limited period in which such a claim can be made. It would be sensible to provide that this period should start no earlier than publication of the draft cross-border conversion terms and end before the conversion takes effect (for example when the pre-conversion certificate is issued or a set period after publication of the draft cross-border conversion terms). As in the case of a cross-border merger or a cross-border division, in order to give the company certainty it should be clear that a creditor will be deemed not to be prejudiced if an independent expert concludes that there is no reasonable likelihood that the creditor will be prejudiced or if the creditor is offered a claim of equivalent value which may be brought in the same jurisdiction as their original claim. This latter approach would mean that a creditor would not be required to bring proceedings in a different Member State, which might involve extra costs and difficulties for them.

\subsection{Minority shareholder protection}

A shareholder may wish to vote against a proposed conversion for many reasons, including that the law of the Member State chosen for the conversion may not offer them the same protections as the law of the original Member State or that their rights as shareholder will not be available under the law of the Member State chosen for the conversion. The converting company should therefore be required to offer to acquire the shares of a shareholder who votes against the proposal (or who has non-voting securities and cannot vote against the proposal) for adequate cash compensation, conditional on the conversion taking place. If the shareholder believes that the cash compensation has been set inadequately, the shareholder should be able to demand adequate compensation within a stated period after the general meeting. This compensation should be determined by a competent authority in the original Member State. The company will be able to protect itself against having to pay out more cash compensation than it wishes by including a condition to that effect in its draft terms of conversion.

\section{Conclusion}

The principle of freedom of establishment for companies has existed for many years. Practical experience has shown that where there is an established procedure for companies to follow (as is the case with the cross-border merger process), companies will take advantage of the freedom of establishment and this contributes to the single 
market. Practical experience has also shown that, without an established procedure for companies to follow, very few companies are able to use the freedom of establishment to divide themselves across borders or to move from one Member State to another. Those that have done this in practice have in many cases had to bring a case before the CJEU to establish their right to do so. Even in the light of such case law, competent authorities of most Member States are unable or unwilling to allow a cross-border division or conversion without an established procedure at EU level.

The proposed company law package offers a significant opportunity to make the principle of freedom of establishment for companies a reality, by improving the crossborder merger process, establishing a process for cross-border divisions and a process for cross-border conversions. Each process has to carefully balance the interests of the company or companies involved and the interests of their shareholders, creditors and other stakeholders. Having a clear process for companies and other interested parties to follow, setting out the circumstances in which interests will be treated as not being prejudiced and setting out when shareholders and creditors can claim protection of their rights will contribute enormously to enabling cross-border mobility to function efficiently and smoothly. This article has set out various ideas as to how the balance between differing interests could be struck and how a more efficient process could work. It is to be hoped that Member States, the Commission and the European Parliament will work constructively together to agree the necessary changes to the Consolidated Directive and make freedom of establishment a reality for companies in the EU.

Open Access This article is distributed under the terms of the Creative Commons Attribution 4.0 International License (http://creativecommons.org/licenses/by/4.0/), which permits unrestricted use, distribution, and reproduction in any medium, provided you give appropriate credit to the original author(s) and the source, provide a link to the Creative Commons license, and indicate if changes were made.

\section{References}

1. Carsten Gerner-Beuerle, C., Mucciarelli, F.M., Schuster, E.-P., Siems, M.M.: Study on the Law Applicable to Companies. Final Report. European Commission, Brussels (2016). Available at: https://publications.europa.eu/en/publication-detail/-/publication/259a1dae-1a8c-11e7-808e01aa75ed71a1/language-en

2. Schmidt, J.: Cross-border mergers and divisions, transfers of seat: is there a need to legislate? Study for the JURI Committee, European Parliament (2016). Available at: http://www.europarl.europa.eu/ RegData/etudes/STUD/2016/556960/IPOL_STU(2016)556960_EN.pdf

3. Simon, F.: EU eyes corporate rules shake up with law on seat transfer (2 October 2017). Available at: http://www.euractiv.com/section/economy-jobs/news/eu-eyes-corporate-rules-shake-up-with-law-onseat-transfer/ 